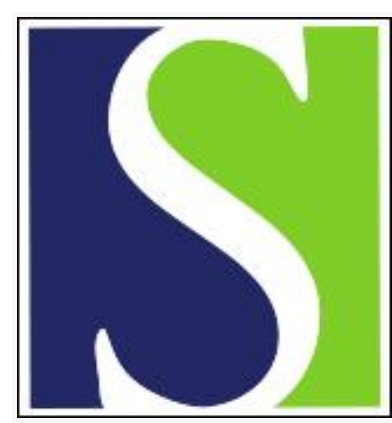

Scand J Work Environ Health 1991;17(6):404-408

https://doi.org/10.5271/sjweh.1686

Issue date: Dec 1991

Relative risk of mesothelioma associated with different levels of exposure to asbestos.

by Tuomi T, Huuskonen MS, Virtamo M, Tossavainen A, Tammilehto L, Mattson K, Lahdensuo A, Mattila J, Karhunen P, Liippo K, et al.

Affiliation: Institute of Occupational Health, Helsinki, Finland.

This article in PubMed: www.ncbi.nlm.nih.gov/pubmed/1788534 


\title{
Relative risk of mesothelioma associated with different levels of exposure to asbestos
}

by Timo Tuomi, MSc, ${ }^{1}$ Matti S Huuskonen, MD, ${ }^{1}$ Matti Virtamo, MSc, ${ }^{1}$ Antti Tossavainen, DTech, ${ }^{1}$ Lauri Tammilehto, MD, ${ }^{2}$ Karin Mattson, MD, ${ }^{2}$ Aarne Lahdensuo, MD, ${ }^{3}$ Jorma Mattila, MD, ${ }^{4}$ Pekka Karhunen, MD, ${ }^{5}$ Kari Liippo, MD, ${ }^{6}$ Eero Tala, MD ${ }^{6}$

\begin{abstract}
TUOMI T, HUUSKONEN MS, VIRTAMO M, TOSSAVAINEN A, TAMMILEHTO L, MATTSON K, LAHDENSUO A, MATTILA J, KARHUNEN P, LIIPPO K, TALA E. Relative risk of mesothelioma associated with different levels of exposure to asbestos. Scand J Work Environ Health 1991;17: 404-8. The relative risk of mesothelioma associated with different levels of exposure to asbestos was evaluated. The exposure was assessed from work histories of 51 mesothelioma cases and 51 sarcoidosis referents. The lung fiber concentration of the mesothelioma patients was compared with that of two reference groups (13 random autopsy cases and 43 male lung cancer patients). When the categories definite and probable were used as an estimated probability of occupational exposure, an odds ratio of 17.7 [90\% confidence interval $(90 \% \mathrm{CI}) 3.4-253$ ] and 3.0 (90\% CI 0.9-10.6), respectively, was obtained. A lung fiber concentration of $>1$ million fibers $/ g$ of dry tissue as an indicator of accumulated exposure gave an odds ratio of 14.4 (90\% CI 2.5-178) for the men in comparison with the autopsy cases and $3.1(90 \%$ $\mathrm{CI}, 1.3-7.5$ ) in comparison with the lung cancer patients. Elevated risk of mesothelioma was shown to be associated with a lung fiber concentration of $>1$ million fibers $/ g$ of dry tissue.
\end{abstract}

Key terms: electron microscopy, mineral fibers, work history.

As in most industrialized countries, the annual incidence of mesothelioma has been rising in Finland, and increasing attention has been paid to it as an occupational disease. The use of asbestos reached its height at the beginning of the 1970s (1), and it is expected that the incidence of mesothelioma will consequently increase, at least during the next 20 years. The annual age-adjusted incidence rate per million of primary pleural tumors (mesothelioma) was five for men and one for women in 1973-1977, seven for men and three for women in 1978-1982, and 12 for men and three for women in 1985 (2). Based on the mesothelioma notifications of the Finnish Cancer Registry in 19531969 , the annual incidence of pleural mesothelioma was estimated to be 1.1 per million, and the male : female ratio was $1.3(3)$. The male:female ratio has been gradually growing, reaching 2.5 in the mid-1980s (2). The incidence numbers are similar to those obtained in the United States and Great Britain in the beginning of the $1980 \mathrm{~s}(4,5)$.

1 Institute of Occupational Health, Helsinki, Finland.

2 Helsinki University Central Hospital, Department of Pulmonary Medicine, Helsinki, Finland.

3 Tampere University Central Hospital, Department of Pulmonary Diseases, Tampere, Finland.

${ }^{4}$ Tampere University Central Hospital, Department of Pathology, Tampere, Finland.

5 University of Helsinki, Department of Forensic Medicine, Helsinki, Finland.

6 Turku University Central Hospital, Department of Thoracic Medicine, Turku, Finland.

Reprint requests to: $\mathrm{Mr} \mathrm{T}$ Tuomi, Institute of Occupational Health, Topeliuksenkatu 41 a A, SF-00250 Helsinki, Finland.
The present study was undertaken to estimate the relative risk of mesothelioma caused by occupational exposure to asbestos. Data on work history and accumulated asbestos exposure, as measured by lung tissue fiber analysis, were utilized.

\section{Subjects and methods}

A total of 57 mesothelioma patients was included in the study. Fifty-one patients were interviewed for work history, and for 30 of them a lung tissue sample was analyzed. For an additional six mesothelioma patients no interview data were available but lung tissue samples were obtained.

The subjects were patients from the Departments of Pulmonary Medicine at the university central hospitals of Helsinki (43 patients), Tampere (8 patients), and Turku (6 patients) in 1985-1988. The source population of the Helsinki University Central Hospital was approximately one million inhabitants from the southern part of Finland, including the capital, Helsinki. The source populations of the two other hospitals together comprised 0.7 million inhabitants from two industrialized cities and their surroundings. All living mesothelioma patients at the start of the study and all new patients during the study period who were available for interview were included. The proportion of mesothelioma patients included from the Helsinki University Central Hospital was more than $70 \%$ of the total number of cases admitted to this hospital in 1985-1988. The main reason for omission was poor general condition. The number of mesothelioma pa- 
tients with a confirmed diagnosis totaled 43 men and 14 women.

\section{Cases and referents}

Part of the study was conducted with the use of a casereferent design. For each mesothelioma case, a sarcoidosis patient, matched for gender and age, was selected as a referent. Altogether 51 case-referent pairs were formed, and the chronological work histories were obtained from the cases and referents in an interview.

The histological diagnosis of mesothelioma was confirmed by a mesothelioma pathology panel according to the diagnostic criteria established by the European Organisation for the Research and Treatment of Cancer $(6,7)$. Three of the 57 mesotheliomas were of peritoneal origin. The distribution of the histological subtypes of the tumors was 25 epithelial, 4 fibrous, and 28 mixed types. In 17 cases the etiology of a suspected pleural finding was later confirmed to be something other than mesothelioma, for example, benign thickening of the pleura or metastatic carcinoma, usually adenocarcinoma. Since the lung fiber analysis was available for these patients, they were included in the study for comparison. This group was, however, not considered appropriate as a reference group in the risk calculations.

The mean age of the mesothelioma patients at diagnosis was 57 (range 39-79) years. Eleven patients were alive at the end of the study period. An autopsy was performed on $33(80 \%)$ of the 41 deceased patients.

The sarcoidosis patients were selected as referents because it was practical to use subjects from the same hospitals as the mesothelioma patients. Sarcoidosis has no known etiology (8). A sarcoidosis referent was chosen for each case through matching for gender and age ( \pm 5 years). The diagnosis of sarcoidosis was based on clinical criteria, bronchoalveolar lavage findings, and a positive result in the Kveim test (9).

Of the mesothelioma patients, $14 \%$ were smokers, $48 \%$ ex-smokers, and $38 \%$ nonsmokers, whereas of the sarcoidosis patients $9 \%$ were smokers, $42 \%$ exsmokers, and $49 \%$ nonsmokers.

In this study we were not able to get information on the lung fiber concentrations of the sarcoidosis referents. The odds ratios for lung fiber concentrations of $>1$ and $>10$ million fibers/g of dry tissue were, however, calculated with recent fiber concentration data of other groups as reference. The results from the lung cancer patients are from a previous Finnish study (10) and from an unpublished series analyzed at the Institute of Occupational Health. The methods for gathering the work histories and for performing the fiber analysis were the same as with the mesothelioma patients. Forty-three male lung cancer patients were included in the study. Their mean age was 60 years.

The data on autopsy and of fice worker groups have been published recently $(11,12)$. These groups were collected from cases autopsied in 1984 at the Department of Forensic Medicine, University of Helsinki. Altogether data from 13 consecutive autopsies of men were included in the study. The mean age at death of the autopsy group was 60 years. The mean age of the nine male office workers was 53 years.

\section{Interview and classification of exposure}

The patients were interviewed by an experienced interviewer during their visit to the hospital or during hospitalization. A chronological work history was obtained, and additional questions were asked about domestic and environmental exposure to asbestos, as well as other suspected causal factors of mesothelioma, like injuries and earlier radiotherapy of the thoracic region $(13,14)$. Unaware of the case-referent status, a panel consisting of two occupational hygienists and an occupational physician then evaluated the probability of the past asbestos exposure. The work history was presented to the panel by one of the interviewers. The panel made a decision on the probability of occupational exposure to asbestos by evaluating the possibilities of exposure in each occupation the subject had held. The exposures were classified into the following four categories: (i) definite exposure: subjects employed in asbestos mining, the manufacture of asbestos products, the asbestos cement industry, asbestos insulation work, or the demolition of old buildings; (ii) probable exposure: subjects employed in shipyards, the construction industry, or metal workshops; (iii) possible exposure: subjects employed in various trades with dust exposure such as mining, power plants, transportation, or the paper and pulp industry; and (iv) unlikely exposure: subjects employed in occupations with no evidence of asbestos exposure. An exposure time of one month was regarded as the minimum $(11,15)$.

\section{Determination of fiber concentration in lung tissue}

The lung tissue samples from 36 mesothelioma patients (31 men and 5 women) were obtained during diagnostic thoracotomy or autopsy. Fibers were counted both by scanning electron microscopy (SEM) and transmission electron microscopy (TEM), and the asbestos minerals were identified with $\mathrm{X}$-ray microanalysis (12, 16).

When the groups with definite and probable exposure were combined, $85 \%$ of the patients had fiber concentrations of $>1$ million fibers/g of dry tissue. In the group with possible exposure and that with unlikely exposure the corresponding percentages were 50 and $27 \%$, respectively.

\section{Statistical methods}

The odds ratios were calculated by an asymptotic method (17) from the case-referent pairs (mesothelioma-sarcoidosis) matched for gender and age and by 
an exact estimation of the odds ratio (OR) for a nonmatched age stratified series of mesothelioma patients, autopsy cases, and lung cancer patients $(18,19)$.

\section{Results}

Table 1 lists the exposure classification of the mesothelioma and sarcoidosis patients. According to the work history, nine mesothelioma patients $(18 \%)$ and none of the sarcoidosis patients had been employed in occupations with definite exposure to asbestos. Ten $(20 \%)$ of the mesothelioma patients and 10 of the sarcoidosis patients had been employed in occupations with probable exposure. Taken together, $37 \%$ of the mesothelioma patients ( $51 \%$ of the men) and $20 \%$ of the sarcoidosis patients ( $27 \%$ of the men) had been working in occupations with at least probable exposure to asbestos.

Only one of the 14 female mesothelioma patients and one of the female sarcoidosis patients were assessed to have had possible exposure to asbestos, while for the rest exposure was unlikely.

Table 1. Exposure classification of the 51 mesothelioma patients and 51 sarcoidosis referents with a known work history.

\begin{tabular}{lrrrrr}
\hline \multirow{2}{*}{ Exposure class } & \multicolumn{2}{c}{ Cases } & & \multicolumn{2}{c}{ Referents } \\
\cline { 2 - 3 } \cline { 6 - 7 } \cline { 6 - 7 } & Men & Women & & Men & Women \\
\hline Definite & 9 & - & & - & - \\
Probable & 10 & - & & 10 & - \\
Possible & 8 & 1 & & 11 & 1 \\
Unlikely & 10 & 13 & & 16 & 13 \\
\hline Total & 37 & 14 & & 37 & 14 \\
\hline
\end{tabular}

Table 2. The distribution of 36 mesothelioma patients accord ing to lung fiber burden.

\begin{tabular}{lcc}
\hline $\begin{array}{l}\text { Fiber concentration } \\
\text { in lung tissue } \\
\text { (fibers/g dry tissue) }\end{array}$ & \multicolumn{2}{c}{$\begin{array}{c}\text { Mesothelioma } \\
\text { patients }\end{array}$} \\
\cline { 2 - 3 } & $\mathrm{N}$ & $\%$ \\
\hline$<1 \times 10^{6}$ & 14 & 39 \\
$\geq 1 \times 10^{6}$ & 22 & 61 \\
$>10 \times 10^{6}$ & 15 & 42 \\
$>100 \times 10^{6}$ & 6 & 17 \\
$>1000 \times 10^{6}$ & 2 & 6 \\
\hline
\end{tabular}

The mean latency period calculated from the start of the work period with exposure to asbestos to diagnosis was 35 (range 21-55) years for the 28 mesothelioma patients with at least possible exposure. The mean time spent in occupations with asbestos exposure was 22 (range 6-39) years.

Table 2 shows the distribution of the 36 mesothelioma patients with respect to the fiber concentration in the lung tissue as measured with SEM. The limit of 1 million fibers/g of dry tissue was used as an indicator for occupational exposure $(12,20)$. Sixty-one percent of the mesothelioma patients had a lung fiber concentration of $>1$ million fibers $/ g$ of dry tissue and $42 \%$ had a concentration of $>10$ million fibers $/ g$ of dry tissue. The lung fiber concentration of the five women in the analysis was $<1$ million fibers/g of dry tissue with SEM. However the fiber concentrations of two of them, as analyzed with TEM, were between 3 and 5 million fibers/g of dry tissue, and this finding suggests some form of exposure.

Table 3 presents the distributions of five Finnish patient groups according to a lung fiber concentration of 1 million fibers/g of dry tissue (SEM). The nonmesothelioma patients were originally suspected mesothelioma patients of this study, but their diagnosis was confirmed later as being something else, typically bronchial cancer or metastatic carcinoma.

The odds ratios calculated with the use of different reference groups and indicators of asbestos exposure are presented in table 4. The odds ratio (relative risk), calculated from the exposure classification score through a comparison of the asbestos exposure of the mesothelioma patients and sarcoidosis patients, was high and statistically significant in the definite-exposure class. The odds ratio obtained for the probable-exposure class indicated an elevated but not statistically significant risk. No evidence of elevated risk was found for the possible-exposure class.

The odds ratios calculated with 1 million fibers/g of dry tissue as the limit of positive exposure were increased and statistically significant for the men when either the autopsy patients or the lung cancer patients were used as referents. In the comparison with the male lung cancer patients, the odds ratio roughly doubled when a lung fiber burden of 10 million fibers/g of dry tissue was used as the indicator of asbestos exposure.

Table 3. Distribution of different person groups according to lung fiber burden.

\begin{tabular}{lcccrr}
\hline $\begin{array}{l}\text { Fiber concentration } \\
\text { in lung tissue } \\
\text { (fibers/g dry tissue) }\end{array}$ & $\begin{array}{c}\text { Mesothelioma } \\
\text { patients } \\
(\mathrm{N}=36) \\
(\%)\end{array}$ & $\begin{array}{c}\text { Nonmesothelioma } \\
\text { patients } \\
(\mathrm{N}=17) \\
(\%)\end{array}$ & $\begin{array}{c}\text { Lung cancer } \\
\text { patients } \\
(\mathrm{N}=43) \\
(\%)\end{array}$ & $\begin{array}{c}\text { Autopsy } \\
\text { cases } \\
(\mathrm{N}=13) \\
(\%)\end{array}$ & $\begin{array}{r}\text { Office } \\
\text { workers } \\
(\mathrm{N}=9) \\
(\%)\end{array}$ \\
\hline$<1 \times 10^{6}$ & 39 & 76 & 69 & 77 & $\begin{array}{r}100 \\
\geq 1 \times 10^{6}\end{array}$ \\
$<10 \times 10^{6}$ & 61 & 24 & 31 & 23 & 0 \\
$\geq 10 \times 10^{6}$ & 58 & 94 & 93 & 100 & 0 \\
\hline
\end{tabular}




\section{Discussion}

The case-referent design clearly revealed an increased relative risk of mesothelioma in the definite-exposure class, and a suggestive but not statistically significant relative risk in the probable-exposure class. An increased relative risk was not found for the possibleexposure class.

We did not attempt to quantitate the intensity of asbestos exposure from the work history; instead only the probability that a person had been exposed to asbestos for more than one month was estimated. The evaluation of exposure to asbestos, especially in construction work, was often difficult because the work history lacked reliable information. In general, the concentration of fibers in the lungs was greater for the persons with a higher probability of exposure, as assessed from the work history (11).

No referents were classified into the definite-exposure category, but probable exposure to asbestos was rather prevalent $(20 \%)$ among the male sarcoidosis referents. This result shows that occupational exposure to asbestos among the Finnish male population was common in the 1960s and 1970s. The conclusion from the other reference groups was the same; according to the autopsy data, about one-fifth of Finnish men over 40 years of age has been occupationally exposed to asbestos. From the available information, an approximation can also be made that about $20 \%$ of Finnish men in the age classes comparable to the mesothelioma patients has lung fiber concentrations of $>1$ million fibers/g of dry tissue.

Twenty-seven percent of the interviewed mesothelioma patients were women; this percentage corresponds to the average of all the total new cases in 1978-1985 (2). The histological subtype of mesothelioma in the female patients was pleural. Occupational exposure to asbestos was suspected for only one of the female patients. She had worked for almost four decades from 1940 on with a paper sack machine in a paper mill. No tissue sample for fiber analysis was available from her. The other female mesothelioma patients had not been occupationally exposed to asbestos. The mean annual incidence rate of mesothelioma in the women was threefold in 1985, whereas the corresponding incidence for the men was 2.5 -fold when compared with the average figures from 1973-1977 (2). This finding suggests that the increased incidence among the men and women can be attributed to the increased occurrence of asbestos at work and in the general environment.

Generally speaking, the exposure evaluation from the lung tissue analysis gave a higher percentage $(61 \%)$ of exposed mesothelioma patients than was revealed by the work history $(38 \%)$. In the comparison with the lung fiber concentration of the reference group of autopsy patients, the concentration of 1 million fibers/g of dry tissue, as an indicator of occupational exposure to asbestos, gave a relative risk estimate of 14.4 for the men, a value similar to the level associated
Table 4. Odds ratios (OR) for mesothelioma according to asbestos exposure, as assessed from the work histories of both the men and the women and the lung fiber analysis of the men. $(90 \% \mathrm{Cl}=90 \%$ confidence interval)

\begin{tabular}{|c|c|c|}
\hline Indicator of exposure & OR & $90 \% \mathrm{Cl}$ \\
\hline \multicolumn{3}{|l|}{ Work history } \\
\hline \multicolumn{3}{|l|}{$\begin{array}{l}\text { Mesothelioma patients }(N=51) \\
\text { versus sarcoidosis patients }(N=51)\end{array}$} \\
\hline $\begin{array}{l}\text { Definite } \\
\text { Probable } \\
\text { Possible }\end{array}$ & $\begin{array}{r}17.7 \\
3.0 \\
1.0\end{array}$ & $\begin{array}{l}3.4-253 \\
0.9-10.6 \\
0.4-2.7\end{array}$ \\
\hline \multicolumn{3}{|l|}{ Lung fiber concentration } \\
\hline \multicolumn{3}{|l|}{$\begin{array}{l}\text { Mesothelioma patients ( } 31 \text { men) } \\
\text { versus autopsy cases (13 men) }\end{array}$} \\
\hline$\geq 1$ million fibers/g dry tissue & 14.4 & $2.5-178$ \\
\hline \multicolumn{3}{|l|}{$\begin{array}{l}\text { Mesothelioma patients ( } 31 \text { men) } \\
\text { versus lung cancer patients } \\
\text { ( } 43 \text { men) }\end{array}$} \\
\hline $\begin{array}{l}\geq 1 \text { million fibers } / g \text { dry tissue } \\
>10 \text { million fibersig dry tissue }\end{array}$ & $\begin{array}{l}3.1 \\
7.2\end{array}$ & $\begin{array}{l}1.3-7.5 \\
2.5-23.4\end{array}$ \\
\hline
\end{tabular}

with definite exposure (OR 17.7), but higher than with exposure class probable (OR 3.0). On the other hand, all of the mesothelioma patients in the probable-exposure class had lung fiber concentrations of $>1$ million fibers/g of dry tissue. This finding suggests that lung fiber analysis usually gives a better and more reliable estimate of past exposures to asbestos, even if a thorough work history is available, and lung fiber burden is a better predictor of risk. The comparisons with lung cancer patients gave lower estimates of relative risk. Even though the numbers of referents were small, the finding suggests that the lung cancer patients had been more frequently exposed to asbestos than the general population, represented in this study by the autopsy patients.

Few quantitative results have been published on exposure to asbestos and the response of mesothelioma because of the small number of cases with exposure information (21). A recent Canadian case-referent study estimated the relative risk of mesothelioma attributed to a cumulative dose of different types of fibers (22). The relative risk increased as the fiber concentration in the lungs increased, especially for long $(\geq 8 \mu \mathrm{m})$ fibers. This increase was not seen for short chrysotile fibers.

In a Norwegian case-referent study of 14 mesothelioma patients and 28 referents, an odds ratio of 8.5 was obtained when the lung burden of 1 million fibers/g of dry tissue (SEM) was used as an indicator of accumulated exposure to asbestos (15). According to the work histories, $77 \%$ of the mesothelioma patients had had at least probable exposure to asbestos. Judging from the lung tissue fiber burden, a somewhat greater percentage $(86 \%)$ was regarded as exposed. In the reference group, $25 \%$ had been exposed according to both their work history (probable exposure) and their lung fiber concentration. Although the criteria for evaluating work history in the Norwegian study gave apparently higher proportions of exposed patients, the results are comparable with ours. In the recent Aus- 
tralian study of 221 definite and probable cases of mesothelioma and 359 autopsy referents statistically significant dose-response relationships were found between the odds ratio and the lung fiber concentration (23). In fiber analysis with TEM, the odds ratio for increased concentrations, in comparison with $<200000$ fibers/g of dry tissue, was calculated. The odds ratio for a tenfold increase in fiber concentration according to fiber type and length was 2.3 for amosite $(<10 \mu \mathrm{m}), 15.7$ for chrysotile $(<10 \mu \mathrm{m})$, and 29.4 for crocidolite $(\geq 10 \mu \mathrm{m})(23)$.

Some of the clinically and histologically confirmed mesothelioma patients had no occupational, familial, or environmental exposure to asbestos, as assessed from anamnestic information or from lung fiber burden. The results of lung burden overlapped with those obtained from different reference groups. On the other hand, no indication of other suspected etiologic factors such as ionizing radiation, chronic inflammation, or injuries of the chest area was noted $(13,14)$. Some asbestos fibers were nevertheless found in the lungs of also those mesothelioma patients who had low total fiber counts. Thus the results do not support the existence of a threshold concentration or exposure to asbestos in causing mesothelioma. The fact that the groups with the highest relative risk also had the highest concentration of fibers in their lungs merely suggests that those who have the same types of fibers in lower concentrations carry a smaller risk.

\section{Acknowledgments}

We wish to express our sincere thanks to Ms R Vesanto-Paavola, Ms SL Isola, and Ms T Santala, who interviewed the patients, to $\mathrm{M}$ Nurminen, $\mathrm{PhD}$, who helped with the statistical calculations, to E Vanhala, MSc, and A Karjalainen, MD, who analyzed the autopsy samples, to $\mathrm{H}$ Tiitinen, MD, who helped to organize the interviews, to $\mathrm{H}$ Planteydt, $\mathrm{MD}$, and $\mathrm{S}$ Anttila, MD, for the histological confirmations of the tumors, and to T Kaustia, MA, for the linguistic revision of the manuscript.

The study was supported by the Finnish Work Environment Fund.

\section{References}

1. Huuskonen MS, Ahlman K, Mattson T, Tossavainen A. Asbestos disease in Finland. J Occup Med 1980;22: $751-4$.

2. Finnish Cancer Registry. Cancer incidence in Finland XXX/1985: cancer statistics of the National Board of Health. Helsinki: Finnish Cancer Registry, 1989.

3. Nurminen M. The epidemiologic relationship between pleural mesothelioma and asbestos exposure. Scand J Work Environ Health 1975;1:128-37.

4. Spirtas R, Beebe GW, Connelly RR, et al. Recent trends in mesothelioma incidence in the United States. Am J Ind Med 1986;9:397-407.

5. Jones RD, Smith DM, Thomas PG. Mesothelioma in Great Britain in 1968-1983. Scand J Work Environ Health 1988;14:145-52.

6. Bolen JW, Hammar SP, McNutt MA. Reactive and neoplastic serosal tissue: a light-microscopic, ultrastructural and immunocytochemical study. Am J Surg Pathol 1986; 10:34-7.

7. Whitaker D, Shilkin KB. Diagnosis of pleural malignant mesothelioma in life - a practical approach. J Pathol 1984;143:147-75.

8. James DG, Turiaf J, Hosoda Y. Description of sarcoidosis: report of the subcommitee on classification and definition. Ann NY Acad Sci 1976;278:742.

9. Seaton A, Seaton D, Leight AG. Sarcoidosis. In: Seaton A, Seaton D, Leitc AG, ed. Crofton and Douglas's respiratory diseases. 4th edition. London: Blackwell Scientific Publications, 1989:630-59.

10. Anttila S, Heikkilä L, Husgafvel-Pursiainen $\mathrm{K}$, et al. Asbestin osuus keuhkosyövän ja fibroosin synnyssä [Asbestos as a cause of lung cancer and fibrosis]. Työ ja ihminen 1990;4:241-56. (English abstract.)

11. Tuomi T, Huuskonen MS, Tammilehto L, Vanhala E, Virtamo M. Occupational exposure to asbestos as evaluated from work histories and lung tissue analysis of mesothelioma patients. Br J Ind Med 1991;48:48-52.

12. Tuomi T, Segerberg-Konttinen M, Tammilehto L, Tossavainen A, Vanhala E. Mineral fiber concentration in lung tissue of mesothelioma patients in Finland. Am J Ind Med 1989;16:247-54.

13. Peterson JT, Greenberg SD, Buffler PA. Non-asbestos related malignant mesothelioma. Cancer 1984;54:951— 60.

14. Pelnar PV. Further evidence of nonasbestos related mesothelioma: a review of the literature. Scand J Work Environ Health 1988;14:141-4.

15. Mowe G, Gylseth B, Hartveit F, Skaug V. Fiber concentration in lung tissue of patients with malignant mesothelioma. Cancer 1985;56:1089-93.

16. Tuomi T. Fibrous minerals in the lungs of mesothelioma patients: comparison between data on SEM, TEM and personal interview information. Am J Ind Med (in press).

17. Breslow NE, Day NE. Statistical methods in cancer research; vol 1 (The analysis of case-control studies). Lyon: International Agency for Research on Cancer (IARC), 1980. (IARC scientific publications; no 32.)

18. CYTEL Software Corp. StatXact: statistical software for exact nonparametric inference. Cambridge: Cytel Software Corp, 1989.

19. Nurminen M, Mutanen P. Exact Bayesian analysis of two proportions. Scand J Stat 1987;14:67-77.

20. Gylseth B, Mowé G, Skaug V, Wannag A. Inorganic fibers in lung tissue from patients with pleural plaques or malignant mesothelioma. Scand $\mathbf{J}$ Work Environ Health 1981;7:109-13.

21. McDonald AD, McDonald JC. Epidemiology of malignant mesothelioma. In: Antman K, Aisner, J, ed. Asbestos related malignancy. Boston, MA: Grune \& Strattoli, 1987:31-55.

22. McDonald JC, Armstrong B, Case B, et al. Mesothelioma and asbestos fiber type; evidence from lung tissue analyses. Cancer 1989;63:1544-7.

23. Rogers AJ, Leigh J, Berry G, Ferguson DA, Mulder HB, Ackad M. Relationship between lung asbestos fiber type and concentration and relative risk of mesothelioma. Cancer 1991;67:1912-20.

Received for publication: 3 May 1991 